\title{
Mechanical Performances of Boards Made from Carbonized Rice Husk and Sawdust: The Effect of Resin and Sawdust Addition Ratio
}

\author{
Jung-Woo HWANG ${ }^{2} \cdot$ Seung-Won OH(D ${ }^{2, \uparrow}$
}

\begin{abstract}
A board was manufactured for each resin and sawdust addition using the chaff made by carbonizing the chaff charcoal, an agricultural by-product that emerge during the rice pounding process, and sawdust. And effects of the additions of resin and sawdust on coefficients of dynamic and static modulus of elasticity, modulus of rupture, as well as the relationship between the dynamic modulus of elasticity, statis modulus of elasticity, and modulus of rupture were investigated. As phenol resin addition of chaff charcoal-sawdust compound boardincreases to 10 25\%, the bending performance has increased. This suggests that resin addition largely effects the bending performance. Although the bending performance was gradually increased with the increase in sawdust addition, since the coefficients of determination $\left(\mathrm{R}^{2}\right)$ between the sawdust addition with the coefficients of dynamic, static modulus of elasticity, and modulus of rupture were $0.4012,0.0809$, and 0.1971 , respectively. Thus, it showed a relatively lower correlation, and the effect of sawdust on bending performance was small. Since a high correlation was confirmed between dynamic and static modulus of elasticity, and modulus of rupture of chaff charcoal-sawdust compound board, it was confirmed that prediction of static modulus of elasticity and modulus of rupture can be made in a nondestructive way from the dynamic modulus of elasticity.
\end{abstract}

Keywords: carbonized rice husk, sawdust, MOR, dMOE, sMOE

\section{INTRODUCTION}

As most of modern life is carried out indoor, and with problems related to indoor environment and interests in health of individuals, interests in eco-friendly construction materials of wood and wooden materials is increasing. Furthermore the wooden materials which were manufactured with conventional materials are slowly switching to eco-friendly materials that combined materials with functionality. In particular, re- search and development are being made on various eco-friendly materials that consider durability and functionality (Park et al., 2011, 2012; 2013; Ahn, 2009).

Charcoal is a standing out eco-friendly material which can be most easily accessed, and it has been utilized for various uses such as air purification, deodorization, and protection against gases, etc. from the past. As the advantage of an easy accessibility as well as other various functionalities such as deodorization, preservation, filtration, humidification, negative ion

\footnotetext{
${ }^{1}$ Date Received July 30, 2020, Date Accepted August 30, 2020

2 Department of Wood Science \& Technology, Jeonbuk National University, Jeonju 54896, Republic of Korea

$\dagger$ Corresponding author: Seung-Won OH (e-mail: ohsw@jbnu.ac.kr, ORCID: 0000-0002-6601-9789)
} 
Mechanical Performances of Boards Made from Carbonized Rice Husk and Sawdust:

The Effect of Resin and Sawdust Addition Ratio

generating effect, and electromagnetic shielding, etc. have come to the fore, manufacturing and demand of charcoal are increasing accordingly. Thus, numerous studies are being conducted recently on charcoal as an important raw material for studies on the ecofriendly materials (Park et al., 2011, 2012, 2013; Ahn, 2009; Park and Park, 2011; Kim, 2017; Hwang and Oh, 2017, 2020). Chaff charcoal among other types of charcoal is a strong material for insulation, moisture control, negative ion generation, far-infrared radiation, absorbing toxic substances and odor, mothproofing, and also strong against decomposition in a level comparable to glass-wool insulator which is commonly used. Therefore studies are conducted to develop the chaff charcoal with its excellent insulation performance as an eco-friendly insulating material (Ahn et al., 2013; Lee et al., 2013). A large amount of approximately 1.1 million tons (which is equivalent to $20 \sim 25 \%$ of rice production) of chaff is used in manufacturing the chaff charcoal production each year in Korea. However, it is being problematic as its apparent density is $0.097 \sim 0.125 \mathrm{~g} / \mathrm{cm}^{3}$, and it has a large volume when discarded. In addition, it also has a disadvantage where it cannot be disintegrated easily even after being buried due to its low caloric value and high ash content. Thus, it has been mainly used as agricultural compost, and desiccant at a pigsty, etc. (Baek et al., 1998; Kim et al., 2001). Moreover, with usingthe chaff as a material for manufacturing a wooden board, the moisture penetration rate is merely $1 / 3$ of that of sawdust due to its surface covered with setae and siliceous. It also has a difficulty of commercializing in the field of wooden materials since it has poor plasticity and adhesiveness in contrast to lumber (Lee, 1999). However, based on the fact that chaff has about $40 \sim 50 \%$ of carbon component, and about $30 \sim 40 \%$ of silicon content, studies are being conducted recently on manufacturing activated carbon from a carbonized chaff and on ceramic made of sawdust and an agricul- tural by-product of chaff (Oh and Park, 2010; Oh et al., 2005). If the chaff charcoal manufactured by carbonizing the chaff is used as a rawmaterial of a wooden panel product for production, it is expected to achieve various effects such as increasing farm household income, substitution effect of importing lumber, and a large benefit in construction process.

In the meantime, for classification or grading of the lumber products, a nondestructive assessment technologyusing vibration or sound wave on lumber without altering the function of its final use is widely being used (Byeon et al., 2004, 2011; Jin et al., 2015). One method of assessments is using dynamic modulus of elasticity, and the dynamic modulus of elasticity is mostly estimated by measuring acoustic transfer speed or resonant frequency. The acoustic transfer speed can be estimated by using an impact hammer, and the resonant frequency can be estimated by frequency analysis of either vibration or impact hammer.

In this study the static modulus of elasticity, modulus of rupture, and bending strength of a chaff charcoal-sawdust compound board manufactured with differentiated additions of resin and sawdust are measured. Furthermore, it applied both-ends free bending vibration measuring method which is frequently used amongst nondestructive assessment methods to generate the resonant frequency. Then, the frequency was used to calculate the dynamic modulus of elasticity, and analyzed its relationship with the bending strength characteristic.

\section{MATERIALS and METHODS}

\subsection{Testing materials}

For the chaff charcoal used for manufacturing the board, the charcoal from Daewon GSI Co., Ltd. located in Gyeongsangbuk-do was used. For the sawdust, the dust emerged during the sawing process of 
Table 1. Characteristics of phenol-formaldehyde resin for the test

\begin{tabular}{cc}
\hline Items & Resin types \\
\hline \hline Solid content $(\%)$ & $\begin{array}{c}\text { Powder resin } \\
\text { (novolak type) }\end{array}$ \\
Melting point $\left({ }^{\circ} \mathrm{C}\right)$ & 89 \\
Celation time $(\mathrm{sec})$. & $80 \sim 95$ \\
Plate flow $(\mathrm{mm})$ & $30 \sim 35$ \\
\hline
\end{tabular}

pinus radiata was received from a sawmill and utilized. For the uniformity of the samplesat the time of manufacturing the board, the size of particles was selected as 10 20 mesh, and the moisture content was controlled below $9 \%$. For the purpose of manufacturing the board, phenol-formaldehyde resin (Kolon Industries Inc., KNB-100PL) was used. The characteristics of the resin are shown in the Table 1.

\subsection{Manufacturing of the board}

In order to manufacture the board, the phenol-formaldehyde resin was sufficiently combined with the uniformly selected chaff charcoal and sawdust. Then, it was inserted into a stainless square mold located on the plate of a thermal compressor. The height of the upper sample was adjusted consistently, and the sample was thermo-pressure molded to manufacture the board with the dimension of $260 \mathrm{~mm} \times 260 \mathrm{~mm} \times$ $11 \mathrm{~mm}$. For the manufacturing condition of the board, the density was fixated to $0.6 \mathrm{~g} / \mathrm{cm}^{3}$, the sawdust addition as $10 \%$, resin additions as $10,15,20$ and $25 \%$, and density as $0.6 \mathrm{~g} / \mathrm{cm}^{3}$, resin addition as $10 \%$, and sawdust additions as $10,15,20,25$ and $30 \%$, producing four boards for each condition, total of 36 boards. At this point, the thermo pressure temperature was set at $190^{\circ} \mathrm{C}$, the pressure was set at $45 \mathrm{kgf} / \mathrm{cm}^{2} \rightarrow 35 \mathrm{kgf} /$ $\mathrm{cm}^{2} \rightarrow 20 \mathrm{kgf} / \mathrm{cm}^{2}$ (3-phase pressurization), and pressurization time as 6 minutes $\rightarrow 5$ minutes $\rightarrow 4$ minutes (3-phase pressurization time). In order to maintain a uniform thickness of the board during the pressuriza- tion process, a distance bar was used. Furthermore, a Teflon plate was used to prevent attachment of upper, lower surfaces of the board with the thermal plate due to the heat.

\subsection{Property measurement}

\subsubsection{Dynamic modulus of elasticity measurement}

An accelerometer (B\&K) for receiving vibration was attached in the middle of the specimen, and an impact hammer (Type 8203, B\&K) was used to tap its one end lightly. Then, the frequency response function acquired from the impact hammer and accelerometer was analyzed using a FFT analyzer (Type $3065, B \& K)$ to measure natural frequency $\left(f_{0}\right)$. Each specimen was lightly tapped 5 times, and an average natural frequency $\left(f_{0}\right)$ was used to calculate resonance frequency (f) which considered moment of inertia and shear impact, and this resonance frequency was used to estimate the dynamic modulus of elasticity (dMOE). The resonance frequency and dynamic modulus of elasticity were calculated by using the equation (1) and equation (2) (Kataoka and Ono, 1975).

$$
f=f_{0}\left(1+\frac{a h^{2}}{l^{2}}\right)
$$

Here, $f_{0}$ refers to the natural frequency (the value obtained from the frequency analyzer), $a$ is constant 8.2 by vibration form, $h$ is the thickness of specimen, and 1 is the length of specimen. The value $f$, the resonance frequency corrected in the equation (1), was used in the equation (2) to estimate the dynamic modulus of elasticity.

$$
{ }_{d} M O E=\frac{48 \pi^{2} \rho l^{4} f^{2}}{m^{4} h^{2}}
$$

Here, $\rho$ refers to density, 1 is the length of specimen, $f$ is resonance frequency, $m$ is constant 4.73 by 
Mechanical Performances of Boards Made from Carbonized Rice Husk and Sawdust:

The Effect of Resin and Sawdust Addition Ratio

basic vibration, and $\mathrm{h}$ is the thickness of specimen.

\subsubsection{Bending experiment}

The bending strength experiment for the manufactured board was performed according to Korean Industrial Standard KS F 3104-2016. Universal strength tester (Shimadsu, AGS-10 kN, Autograph) was used to measure it with the condition of load speed at $10 \mathrm{~mm} / \mathrm{min}$, and the equations (3) and (4) were used to estimate static modulus of elasticity (sMOE) and bending strength or Modulus of Rupture (MOR).

$$
{ }_{s} M O E=\frac{P l^{3}}{4 b h^{3} y}
$$

Here, $\mathrm{P}$ refers to load, 1 is the length of span, $\mathrm{b}$ is the width of specimen, $\mathrm{h}$ is the thickness of specimen, and $\mathrm{y}$ is displacement.

$$
M O R=\frac{3 P l}{2 b h^{2}}
$$

Here, $\mathrm{P}$ refers to a maximum load, 1 is the length of span, $b$ is the width of specimen, and $h$ is the thickness of specimen.

\section{RESULTS and DISCUSSION}

\subsection{Effect of resin addition amount on mechanical performance}

The values of resonance frequency, bending strength, static modulus of elasticity, and dynamic modulus of elasticity of a board manufactured according to resin additions after fixing the density as $0.6 \mathrm{~g} / \mathrm{cm}^{3}$, and sawdust addition as $10 \%$ were shown in the Table 2 . When the resin addition of the chaff charcoal-sawdust compound board was gradually increased from $10 \%$ to $25 \%$, the following ranges were emerged: $227.53 \sim$ $333.63 \mathrm{~Hz}$ for resonance frequency, 9.22 28.91 MPa for bending strength, 320.62 963.48 MPa for dynamic modulus of elasticity, and 92.06 322.92 MPa for static modulus of elasticity. Overall, it was indicated that resonance frequency, bending strength, dynamic modulus of elasticity, and static modulus of elasticity were all increased as the resin addition increased. This result showed a similar tendency with Kawai et al. (1986) who statedthat adhesiveness between samples were increased as the resin addition increased when manufacturing the board, as well as the study by Lee and Yoon (1994) and Oh et al. (2012) which stated

Table 2. Properties of composite boards made at different resin addition ratio(f: resonant frequency, dMOE: dynamic modulus of elasticity, sMOE: static modulus of elasticity, MOR: modulus of rupture)

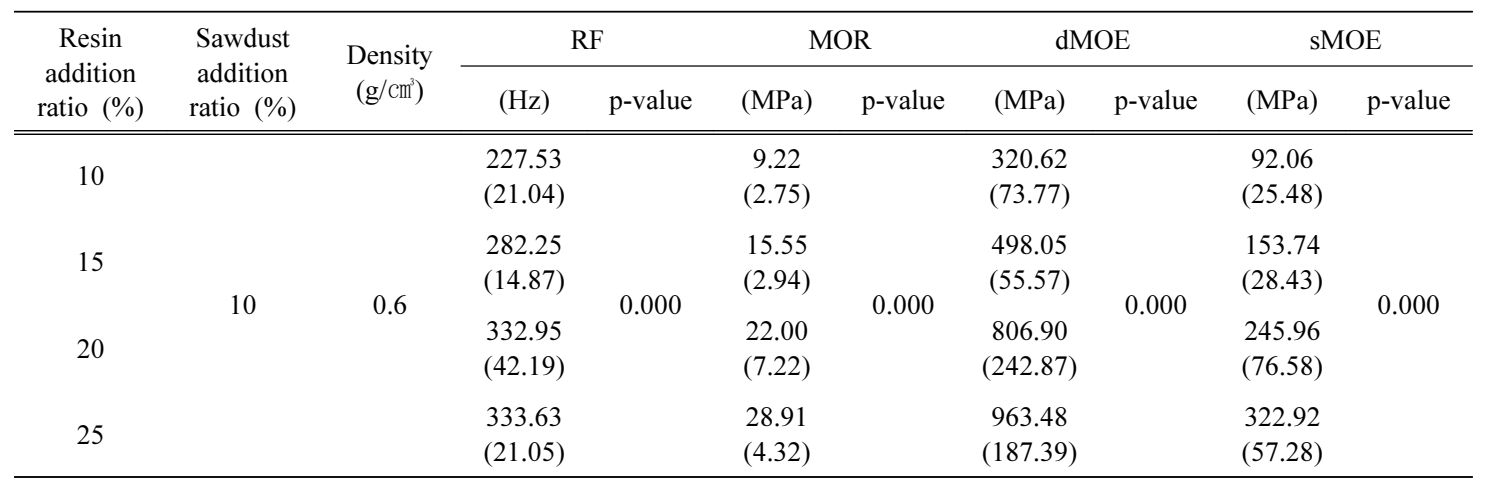

Notes: Numbers in parenthesis are standard deviations. 


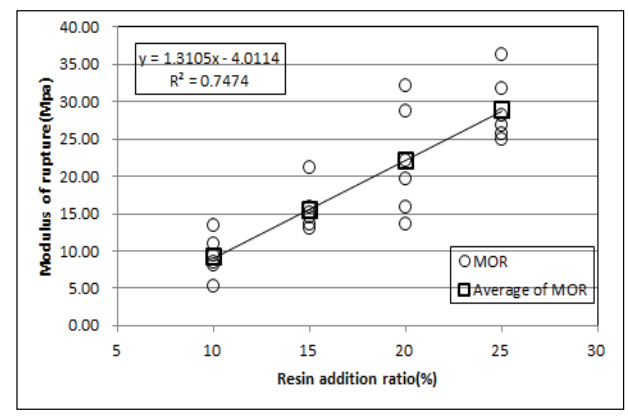

(a)

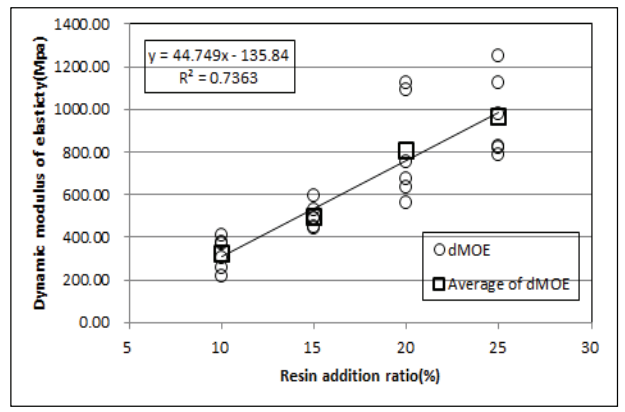

(b)

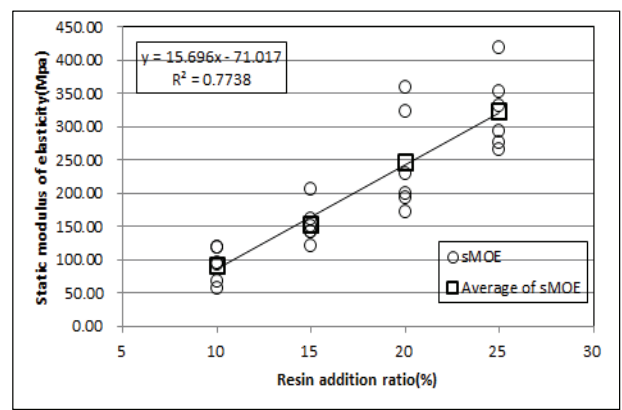

(c)

Fig. 1. Relation between resin addition ratio and mechanical properties of composite boards(a: relation resin addition ratio density and modulus of rupture(MOR), b: relation between resin addition ratio and dynamic modulus of elasticity(dMOE), c: relation between resin addition ratio and static modulus of elasticity(sMOE)).

that bending strength increased as the resin addition increased. Moreover, the bending strength of the board manufactured with the resin addition ratio of $15 \%$ satisfied KS F 3104 particle board's quality standard 15.0 type, whereas the board manufactured with the resin addition ratios of $20 \%$ and $25 \%$ satisfied type 18.0 . In the aspect of mechanical performance, the chaff charcoal-sawdust compound board manufactured with resin addition ratio of $25 \%$ seems to be an optimum condition.

Fig. 1 is the result of analyzing correlation between resin addition ratio, bending strength, dynamic modulus of elasticity, and static modulus of elasticity of the board with the aim of identifying the effect of resin addition ratio on strength performance of the chaff charcoal-sawdust compound board. A lineal correlation is made between resin addition ratio, bending strength, dynamic and static modulus of elasticity, and the coefficients of determination $\left(\mathrm{R}^{2}\right)$ were 0.7474 , 0.7363 , and 0.7738 . Thus, significance level of $1 \%$ was admitted and it was revealed that resin addition ratio was a major factor which largely effects the mechanical properties of the chaff charcoal-sawdust compound board. From this result, it can be determined that the dynamic and static modulus of elasticity, and bending strength can be predicted from the resin addition amount of the chaff charcoal-sawdust compound board.

\subsection{Effect of sawdust addition amount on mechanical performance}

The values of resonance frequency, bending strength, static modulus of elasticity, and dynamic modulus of 
Mechanical Performances of Boards Made from Carbonized Rice Husk and Sawdust:

The Effect of Resin and Sawdust Addition Ratio

Table 3. Properties of composite boards made at different sawdust addition ratio(f: resonant frequency, dMOE: dynamic modulus of elasticity, sMOE: static modulus of elasticity, MOR: modulus of rupture)

\begin{tabular}{|c|c|c|c|c|c|c|c|c|c|c|}
\hline \multirow{2}{*}{$\begin{array}{l}\text { Sawdust } \\
\text { addition } \\
\text { ratio }(\%)\end{array}$} & \multirow{2}{*}{$\begin{array}{c}\text { Resin } \\
\text { addition } \\
\text { ratio }(\%)\end{array}$} & \multirow{2}{*}{$\begin{array}{c}\text { Density } \\
\left(\mathrm{g} / \mathrm{cm}^{3}\right)\end{array}$} & \multicolumn{2}{|c|}{$\mathrm{RF}$} & \multicolumn{2}{|c|}{ MOR } & \multicolumn{2}{|c|}{$\mathrm{dMOE}$} & \multicolumn{2}{|c|}{ sMOE } \\
\hline & & & $(\mathrm{Hz})$ & p-value & (MPa) & $\mathrm{p}$-value & (MPa) & p-value & (MPa) & p-value \\
\hline 10 & & & $\begin{array}{l}222.73 \\
(19.51)\end{array}$ & & $\begin{array}{c}8.41 \\
(2.11)\end{array}$ & & $\begin{array}{l}320.62 \\
(73.77)\end{array}$ & & $\begin{array}{c}86.50 \\
(24.22)\end{array}$ & \\
\hline 15 & & & $\begin{array}{l}242.89 \\
(12.78)\end{array}$ & & $\begin{array}{c}9.66 \\
(0.63)\end{array}$ & & $\begin{array}{l}348.85 \\
(28.61)\end{array}$ & & $\begin{array}{l}93.29 \\
(7.34)\end{array}$ & \\
\hline 20 & 10 & 0.6 & $\begin{array}{l}243.40 \\
(16.02)\end{array}$ & 0.075 & $\begin{array}{c}8.89 \\
(1.98)\end{array}$ & 0.000 & $\begin{array}{l}346.79 \\
(50.49)\end{array}$ & 0.159 & $\begin{array}{l}95.01 \\
(8.40)\end{array}$ & 0.026 \\
\hline 25 & & & $\begin{array}{l}244.49 \\
(23.97)\end{array}$ & & $\begin{array}{l}12.03 \\
(2.17)\end{array}$ & & $\begin{array}{l}366.04 \\
(83.98)\end{array}$ & & $\begin{array}{l}104.55 \\
(20.30)\end{array}$ & \\
\hline 30 & & & $\begin{array}{c}244.82(7 . \\
93)\end{array}$ & & $\begin{array}{l}12.46 \\
(1.48)\end{array}$ & & $\begin{array}{l}367.81 \\
(45.24)\end{array}$ & & $\begin{array}{l}106.54 \\
(12.88)\end{array}$ & \\
\hline
\end{tabular}

Notes: Numbers in parenthesis are standard deviations.

elasticity of the board manufactured according to sawdust addition with the density as $0.6 \mathrm{~g} / \mathrm{cm}^{3}$, and resin addition as $10 \%$ were shown in the Table 3 . When the sawdust addition ratio of the chaff charcoal-sawdust compound board increased from $10 \%$ to $30 \%$, the following ranges were emerged: 222.73 244.82 Hz for resonance frequency, 8.41 12.46 MPa for bending strength, 320.62 367.81 $\mathrm{MPa}$ for dynamic modulus of elasticity, and 86.50 106.54 MPa for static modulus of elasticity. Overall, it was shown that as the sawdust addition increased, the resonance frequency, bending strength, dynamic and static modulus of elasticity were increased gradually. This is considered to be for the contribution of sawdust having a large size of raw material and a larger modulus of elasticity than chaff charcoal increases, and that of charcoal having a lower modulus of elasticity than sawdust decreases. This result was consistent with results of other numerous studies reporting that strength performance of a particle board decreases as mixture ratio of different materials with lower strength performance increases (Park et al., 2011, 2012, 2013; Jin et al., 2015). However, although the bending strength of the board manufactured with sawdust addition satisfied KS F 3104 particle board's quality standard type 8 , it is considered to be difficult to use it for durable parts.

Fig. 2 shows the result of analyzing correlation between sawdust addition ratio, bending strength, dynamic modulus of elasticity, and static modulus of elasticity of the board. The aim is to identify the effect of sawdust addition ratio on strength performance of the chaff charcoal-sawdust compound board. This figure reveals the coefficients of determination $\left(\mathrm{R}^{2}\right)$ between sawdust addition ratio, bending strength, dynamic and static modulus of elasticity as 0.4012, 0.0809 , and 0.1971 , respectively, indicating a relatively low correlation. This can be interpreted that sawdust addition rate has a small effect on bending strength performance. In addition, the relationship between sawdust addition ratio, dynamic and bending modulus of elasticity, showed a low significance of $1 \%$. This is considered to be because the effect of addition ratio was small due to the low sawdust addition ratio of the compound board. It seems an additional test is required to be conducted with various addition ratios of sawdust in order to identify optimum manufacturing condition for improving mechanical performance. 


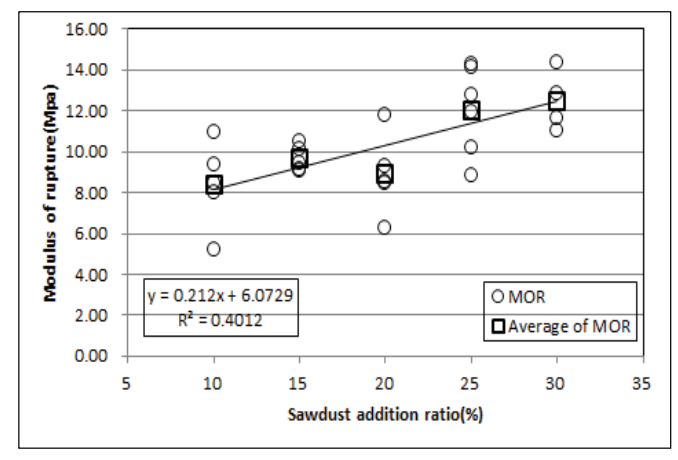

(a)

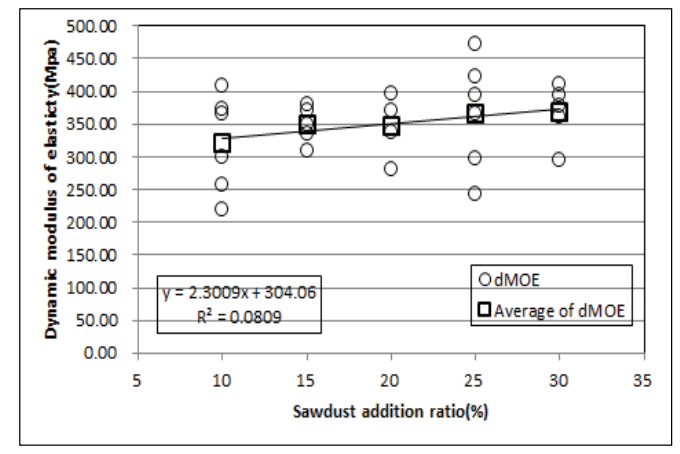

(b)

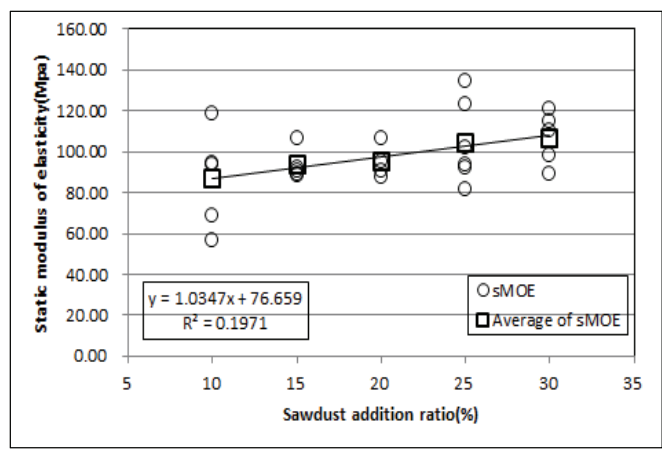

(c)

Fig. 2. Relation between sawdust addition ratio and mechanical properties of composite boards(a: relation sawdust addition ratio density and modulus of rupture(MOR), b: relation between sawdust addition ratio and dynamic modulus of elasticity(dMOE), c: relation between sawdust addition ratio and static modulus of elasticity(sMOE)).

\subsection{The relationship between dynamic modulus of elasticity and static modulus of elasticity}

Table 4 indicates correlation between dynamic modulus of elasticity, static modulus of elasticity, and bending strength of the board manufactured at different addition ratios of resin and sawdust. The coefficients of determination $\left(\mathrm{R}^{2}\right)$ in the relationship between dynamic modulus of elasticity, static modulus of elasticity, and bending strength of the entire chaff charcoal-sawdust compound boards manufactured at different resin addition ratios were 0.9521 and 0.8948 , respectively, and it showed a quite high correlation with confidence level of $1 \%$. Furthermore, the co- efficients of determination $\left(\mathrm{R}^{2}\right)$ in the relationship between dynamic modulus of elasticity, static modulus of elasticity, and bending strength of the entire compound boards manufactured at different sawdust addition ratios were 0.7797 , and 0.7200 , respectively, and this also indicated a high correlation with confidence level of $1 \%$. Fig. 3 shows a correlated regression graph of dynamic modulus of elasticity, static modulus of elasticity, and bending strength of the entire compound boards regardless of resin addition ratio, and sawdust addition ratio of the chaff charcoal-sawdust compound board. The coefficients of determination $\left(\mathrm{R}^{2}\right)$ between dynamic modulus of elasticity, static modulus of elasticity, and bending strength were 0.9612 , and 0.9122 , respectively, and it indicated a quite high 
Mechanical Performances of Boards Made from Carbonized Rice Husk and Sawdust:

The Effect of Resin and Sawdust Addition Ratio

Table 4. Summary of regression parameters for relationships between MOR, sMOE and dMOE(dMOE: dynamic modulus of elasticity, sMOE: static modulus of elasticity, MOR: modulus of rupture)

\begin{tabular}{ccccc}
\hline Parameter & Type & Regression model & $\begin{array}{c}\text { Coefficient of } \\
\text { determination } \\
\mathrm{r}^{2}\end{array}$ & $\mathrm{p}$-value \\
\hline \hline $\mathrm{dMOE}$ vs sMOE & $\begin{array}{c}\text { Different resin } \\
\text { addition ratio }\end{array}$ & $\mathrm{y}=0.3339 \mathrm{x}-12.422$ & 0.9521 & 0.000 \\
$\mathrm{dMOE}$ vs MOR & $\mathrm{y}=0.0275 \mathrm{x}+1.1267$ & 0.8948 & 0.000 \\
\hline $\mathrm{dMOE}$ vs sMOE & $\begin{array}{c}\text { Different } \\
\text { sawdust }\end{array}$ & $\mathrm{y}=0.2456 \mathrm{x}+11.975$ & 0.7797 & 0.000 \\
$\mathrm{dMOE}$ vs MOR & addition ratio & $\mathrm{y}=0.0325 \mathrm{x}-1.3888$ & 0.7200 & 0.000 \\
\hline
\end{tabular}

Note: The model is of the form: $y=a x+b$.

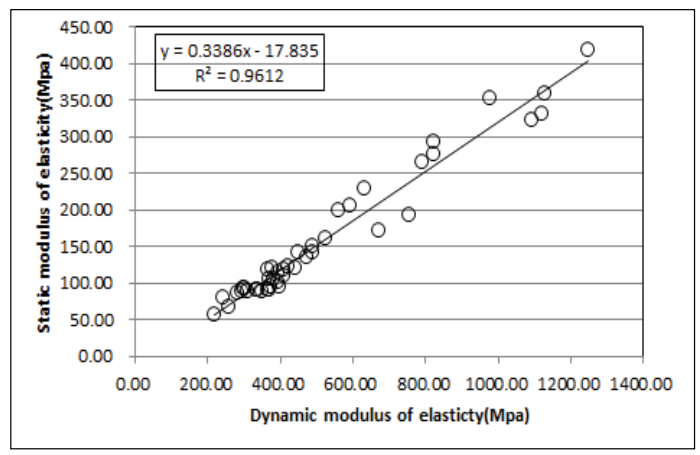

(a)

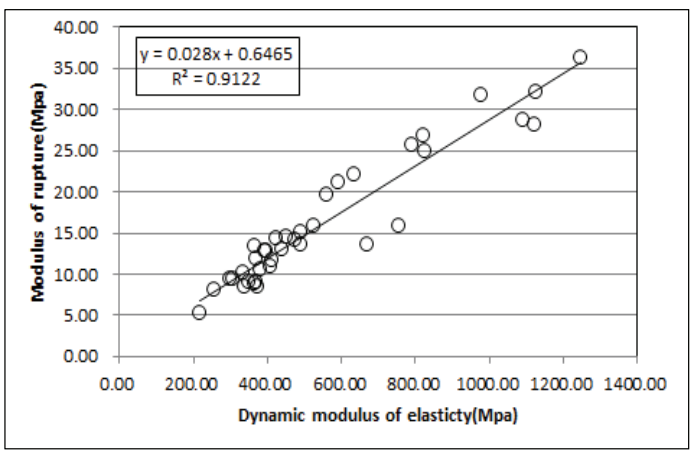

(b)

Fig. 3. Relation between $d M O E$ and $\operatorname{sMOE}(a)$ and $d M O E$ and $M O R(b)$ for the composite boards.

correlation. This result is consistent with many studies reporting that a close correlation is shown between dynamic modulus of elasticity, static modulus of elasticity, and bending strength of lumber and wooden materials (Park et al., 2011, 2012; Jin et al., 2015). Therefore, it is considered to be possible to predict static modulus of elasticity, and bending strength from dynamic modulus of elasticity obtained from the both-ends free bending vibration test.

\section{CONCLUSION}

This study used chaff charcoal made by carbonizing chaff, an agricultural by-product that emerges from rice pounding process, and sawdust to manufacture boards at different addition ratios of resin and sawdust.
In addition, the study investigated the effects of resin and sawdust addition ratios on dynamic, static modulus of elasticity, and bending strength, as well as the relationship between the dynamic modulus of elasticity, the static modulus of elasticity, and thebending strength, and obtained the following results:

1) As resin addition ratio of the chaff charcoal-sawdust compound board increased to $10 \sim 25 \%$, the bending performance increased, indicating that resin addition ratio largely effected the bending performance.

2) Although the bending performance increased gradually with the increase of sawdust addition ratio, the coefficients of determination $\left(R^{2}\right)$ between sawdust addition ratio, bending strength, dynamic and static modulus of elasticity were 
$0.4012,0.0809$, and 0.1971 , respectively, indicating a relatively weak correlation and suggesting that sawdust addition ratio has a small effect on bending performance.

3) Since a high correlation is confirmed between the dynamic modulus of elasticity, the static modulus of elasticity, and bending strength of the chaff charcoal-sawdust compound board, it was confirmed that the static modulus of elasticity, and the bending strength can be predicted nondestructively from the dynamic modulus of elasticity.

It seems to be necessary to conduct a test in the future to manufacture the board by increasing the addition of sawdust by more than $25 \%$, and reducing the ratio of resin addition amount.

\section{REFERENCES}

Ahn, B.J., Jo, T.S., Lee, S.S., Paik, K.H., Kim, S.I. 2009. Utilization of charcoal as an environmentally friendly building materials( I ): Characterization of building materials prepared with charcoal. Journal of the Korean Wood Science and Technology 37(6): 537-545.

Ahn, E.S., Yeom, D.W., Lee, K.I. 2013. The research on the indoor environment performance evaluation of the mock-up with rice hull and charred rice hull mix insulated wall. Proceeding of Academic Conference of Architectural Institute of Korea 33(2): 13-14

Baek, I.H., Bin, H.S., kim, T.Y., kim, K.Y., Nam, K.C. 1998. The manufacture of activated carbon from agricultural by-products and their adsorption performance for the organics. Journal of Korean Society of Environmental Engineers 20(10): 1485-1493.

Byeon, H.S., Ahn, S.Y., Oh, S.W., Piao, J.J. 2004. Nondestructive bending strength evaluation of woodceramics using resonance frequency mode. Journal of the Korean Wood Science and Technology 32(3): 8-14.

Byeon, H.S., Kim, J.M., Won, K.R., Oh, S.W. 2011. Nondestructive bending strength evaluation of woodceramics made from woody part of Broussonetia kazinoki Sieb.: Effect of resin impregnation ratio. Journal of the Korean Wood Science and Technology 39(5): 398-405.

Hwang, J.W., Oh, S.W. 2017. Physical and mechanical properties of board made from carbonized rice husk. Journal of the Korean Wood Science and Technology 45(1): 62-71.

Hwang, J.W., Oh, S.W. 2020. Properties of Board Manufactured from Sawdust, Ricehusk and Charcoal. Journal of the Korean Wood Science and Technology 48(1): 61-75.

Jin, T.Q., Kang, C.W., Oh, S.W., Hwang, J.W. 2015. Effect of density and mixing ratio of mandarin peels of the bending performance of sawdust-mandarin peels particleboards. Journal of the Korean Wood Science and Technology 43(3): 376-385.

Kataoka, A., Ono, T. 1975. The relations of experimental factors to the vibration and the measuring values of dynamic mechanical properties of wood I.: The experimental errors due to the measuring apparatus. Mokuzai Gakkaishi 21: 543-550.

Kawai, S., Suda, H., Nakaji, M., Sasaki, H. 1986. Production technology for low-density particleboard $\Pi$.: Effect of particle moisture and resin content on board properties. Mokuzai Gakkaishi 32(11): 876-882.

Kim, G.C. 2017. A study on the strength properties of board using the carbonized rice husks to develop a structural insulation. Journal of the Korean Wood Science and Technology 45(5): 511-518.

Kim, I.B., Kim, Y.G. 2001. Recycling evaluation of rice-hull and sawdust using carbonization. Journal of korean Society of Environmental Administration 
Mechanical Performances of Boards Made from Carbonized Rice Husk and Sawdust: The Effect of Resin and Sawdust Addition Ratio

7(3): 439-443.

KS F 3104. 2006. Particleboard. Korean Standards Association.

Lee, P.W., Yoon, H.U. 1994. The properties of sawdust board in using MDI (Methylene diphenyldiisocyanate) resin( I ): On the specific gravity, resin additive content and mat moisture content. Journal of The Korea Furniture Society 5(2): 51-61.

Lee, H.H. 1999. Development of rice hull board for the new ecomaterial. Report of Ministry of Agriculture, Food and Rural Affairs.

Lee, K.I., Lee, E.H., Yin, C.R. 2013. Study on the effect of complex use of carbonized rice hull and class wool insulation. Proceeding of Academic Conference of Architectural Institute of Korea 33(2): 15-16

Oh, S.W., Park, H.J., Hwang, J.W. 2012. Characteristics of board made from Miscanthus sinensis var. purpurascens Particles. Journal of Agriculture \& Life Science 46(2): 43-48.

Oh, S.W., Park, S.C. 2009. Properties of boards prepared from woody of Broussonetia Kazinoki Sieb. Journal of the Korean Wood Science and Technology 37(3): 216-221.

Oh, S.W., Piao, J.J., Jeong, I.S. 2005. Properties of ceramics from a board mixed with sawdust and rice husk: Effect of resin impregnation rate and carbonization temperature. Journal of the Korean Wood Science and Technology 33(3): 30-37.

Oh, S.W., Park, H.J. 2010. A change in surface temperature of ceramics made from board mixed with sawdust and rice husk: Effect of resin impregnation rate and carbonization temperature. Journal of the
Korean Wood Science and Technology 38(1): $43-48$

Park, H.M., Heo, H.S., Sung, E.J., Nam, K.H., Lim, J.S. 2013. Effect of the kind and content of raw materials on mechanical performances of hybrid composite boards composed of green tea, charcoals and wood fiber. Journal of the Korean Wood Science and Technology 41(1): 64-76.

Park, H.M., Heo, H.S., Sung, E.J., Nam, K.H., Lim, J.S., Byeon, H.S. 2012. Effect of the kind and content of raw materials on dynamic modulus of elasticity of hybrid composite boards composed of green tea, charcoals and wood fiber. Journal of Agriculture \& Life science 46(6): 75-86.

Park, H.M., Lee, S.K., Seok, J.H., Choi, N.K., Kwon, C.B., Heo, H.S., Byeon, H.S., Yang, J.K., Kim, J.C. 2011. Effect of green tea content on dynamic modulus of elasticity of hybrid boards composed of green tea and wood fibers, and prediction of static bending strength performances by flexural vibration test. Journal of the Korean Wood Science and Technology 39(6): 538-547.

Park, H.M., Lee, S.K., Seok, J.H., Choi, N.K., Kwon, C.B., Heo, H.S., Byeon, H.S., Yang, J.K., Kim, J.C. 2012. Effect of green tea and sawdust contents on dynamic modulus of elasticity of hybrid boards and prediction of static bending strength performances. Journal of Agriculture \& Life Science 46(2): 9-17

Park, S.B., Park, J.S. 2011. Combustion characteristics of bamboo charcoal boards. Journal of the Korean Wood Science and Technology 40(1): 19-25. 


\title{
APPENDIX
}

\author{
(Korean Version)
}

\section{왕겨숯과 톱밥을 이용하여 제조한 보드의 역학적 성능: 수지 및 톱밥첨가량의 영향}

초록 : 쌀의 도정과정에서 발생되는 농업부산물인 왕겨를 탄화시켜 만든 왕겨숯과 톱밥을 이용하여 수지 첨가율, 톱밥 첨가율 별로 보드를 제조하고 수지와 톱밥 첨가율이 동적·정적탄성계수 및 휨강도에 미치는 영향과 동적탄성계수와 정적탄성계수 및 휨강도 사이의 관계를 조사하였다. 왕겨솣-톱밥 혼합보드의 페놀수지 첨가율이 $10 ~ 25 \%$ 로 증가할수록 휨성능이 증가하여 수지 첨가율이 휨성능에 크게 영향을 주었다. 톱밥 첨가율이 증가할수록 휨성능도 완만하게 증가하였지만, 톱밥첨가율과 휨강도, 동적 및 정적 휨 탄성계수 사이는 결정계수의 값 $\left(\mathrm{R}^{2}\right)$ 은 $0.4012,0.0809,0.1971$ 로써 다소 낮은 상관관계를 나타내 톱밥 첨가율이 휨성능에 미치는 영향이 미비하였다. 왕겨숯-톱밥 혼합보드의 동적탄성계수와 정적탄성계수 및 휨강도 사이에 높은 상관관계가 확인되어 동적탄성계수로부터 비파괴적으로 정적탄성계수와 휨강도의 예측이 가능한 것으로 확인되었다.

\section{1. 서 론}

현대인의 생활이 대부분 실내에서 이루어지고 있어 실내 환경에 관한 문제와 개인의 건강에 대한 관심으로 친환경 건축자재인 목재와 목질재료에 대한 관심이 증대되고 있다. 여기에 목질재료는 기존의 목재소재로만 제조되던 것이 점차 기능성이 포함된 재료가 혼합된 친환경재료로 변화하고 있다. 특히, 내구성과 기능성을 고려한 다양한 친환경재료의 연구와 개발이 이루어 지고 있다(Park et al., 2011, 2012; 2013; Ahn, 2009).

솣은 가장 쉽게 접할 수 있는 대표적인 친환경 재료로서 과거에서부터 공기정화, 방취, 방독등의 다양한 용도로 활용되어 왔으며, 구하기 쉽다는 장점과 탈취성능, 방부성능, 여과, 조습성능, 음이온 발생효과, 전자파 차단성능등이 여러 기능성이 부각되면서 그에 따른 생산과 수요가 증가하고 있어서 최근 친환경 재료연구에 중요한 원료로서 많은 연구가 진행되고 있다(Park et al., 2011, 2012, 2013; Ahn, 2009; Park and Park, 2011; Kim, 2017; Hwang and Oh, 2017, 2020). 그 중 왕겨숯은 일반적으로 사용되고 있는 글라스울 단열재에 버금가는 수준의 단열성능, 습도조절, 음이온발생, 원적외선 방출, 유해물질 및 냄새흡수 및 방충 및 부패에 강해 친환경 건축자재로서, 왕겨숯의 우수한 단열성능을 이용해 단열벽체로의 연구가 진행되고 있다(Ahn et al., 2013; Lee et al., 2013). 왕겨숯의 제조에 이용되는 왕겨는 국내에서 연간 약 110 만 톤으로 쌀 생산량의 $20 \sim 25 \%$ 정도로 많은 양이 생산되고 있음에도 불구하고 겉보기 밀도가 $0.097 \sim 0.125 \mathrm{~g} / \mathrm{cm}^{3}$ 이며 폐기 시 부피가 커서 문제가 되고 있으며, 낮은 발열량과 높은 회분함량으로 매립 후에도 쉽게 분해되지 않는 단점을 지니고 있어 주로 농업용 퇴비, 돈사의 방습제 등으로 사용되어 왔다(Baek et al., 1998; Kim et al., 2001). 한편 왕겨를 목질보드 제조용 재료로 이용하는데 있어서도 표면이 강모와 규산질로 덮여있어 수분흡수율이 톱밥의 $1 / 3$ 에 지나지 않으며, 목재와는 달리 성형성 및 접착력이 불량하여 목질재료분 야에서 실용화하기에는 어려운 점이 있다(Lee, 1999). 그러나 왕겨에는 탄소성분이 약 $40 ~ 50 \%$, 규소함량이 $30 ~ 40 \%$ 인 점에 착안하여 최근에는 탄화왕겨로부터 활성탄을 제조하는 연구와 톱밥과 농업부산물인 왕겨로 만든 세라믹에 관한 연구가 진행되 고 있고(Oh and Park, 2010; Oh et al., 2005), 왕겨를 탄화시켜 제조한 왕겨숯을 목질패널 제품의 원료로 이용하여 생산하면 농가소득, 목재수입의 대체효과 및 건축물 시공 시 이점이 클 것으로 생각된다.

한편 최근에 목재생산품의 분류나 등급구분을 하기 위하여 재료의 최종 사용용도 성능을 변화시키지 않으면서 목재에 대한 진동이나 음파를 이용한 비파괴 평가기술이 광범위하게 이용되고 있다(Byeon et al., 2004, 2011; Jin et al., 2015). 평가방법 중에 하나인 동적 탄성계수를 이용하는 방법이 있는데 동적 탄성계수는 주로 음향전달 속도나 공진주파수를 측정하여 구한다. 음향전달속도는 충격해머를 사용하여 구할 수 있고 공진주파수는 진동이나 충격해머의 주파수분석에 의해서도 구할 수 있다.

본 연구에서는 수지 첨가율과 톱밥 첨가율을 달리하여 제조한 왕겨숯-톱밥 혼합보드의 정적 휨 탄성계수와 휨강도를 측정하였 고 비파괴 시험방법 중 흔히 사용되는 양단 자유 휨 진동 측정법을 적용하여 공진주파수를 구한 후 공진주파수를 이용하여 동적 탄성계수를 계산한 후 휨강도 특성과의 관계를 분석하였다. 


\section{2. 재료 및 방법}

\section{1. 공시재료}

보드 제조에 사용된 왕겨숯은 경북에 위치한 (주대원 GSI에서 시판하는 숯을 사용하였고 톱밥은 라디에타 파인(Pinus radiata) 제재 시 발생된 것을 제재소에서 분양받아 사용하였으며, 보드 제조 시 시료의 균일함을 위하여 입자의 크기를 $10 ~ 20$ mesh로 선별하고 함수율은 $9 \%$ 이하로 조절하였다. 보드 제조를 위하여 분말상 페놀수지(코오롱유화(주), KNB-100PL)를 사용하였다. 수지의 특성은 Table 1 과 같다.

\section{2. 보드제조}

보드를 제조하기 위하여 균일하게 선별된 왕겨숯과 톱밥을 분말상 페놀수지를 충분히 혼합하였으며, 열압기의 엽판위에 있는 스테인레스 정방형 몰드 속에 넣고 시료상부의 높이를 일정하게 조절한 후 열압성형 하여 $260 \mathrm{~mm} \times 260 \mathrm{~mm} \times 11$ $\mathrm{mm}$ 의 보드를 제조하였다. 보드 제조 조건은 밀도를 $0.6 \mathrm{~g} / \mathrm{cm}^{3}$, 톱밥 첨가율을 $10 \%$ 로 고정한 후 수지첨가율을 $10,15,20$, $25 \%$, 밀도를 $0.6 \mathrm{~g} / \mathrm{cm}^{3}$, 수지 첨가율을 $10 \%$ 로 고정하고 톱밥첨가율을 $10,15,20,25,30 \%$ 로 설정하여 보드를 각 4 매씩 총 36 매의 보드를 제조하였다. 이때 열압온도는 $190^{\circ} \mathrm{C}$, 가압압력은 $45 \mathrm{kgf} / \mathrm{cm}^{2} \rightarrow 35 \mathrm{kgf} / \mathrm{cm}^{2} \rightarrow 20 \mathrm{kgf} / \mathrm{cm}^{2}($ (단 가압), 가압시간 6 분 $\rightarrow 5$ 분 $\rightarrow 4$ 분 $(3$ 단 가압시간)으로 하였다. 열압과정에서 보드의 두께를 일정하게 하기 위하여 스톱버(distance bar)를 사용하였 으며, 열에 의한 보드의 상하면과 열판의 부착을 방지하기 위하여 테프론 판을 사용하였다.

\section{3. 물성측정}

\subsection{1. 동적탄성계수 측정}

시험편의 중앙에 진동수신을 위한 가속도계(accelerometer, B\&K)를 부착하고, 임팩트 해머(impact hammer, Type 8203, $\mathrm{B} \& \mathrm{~K})$ 로 한쪽 끝을 가볍게 두드려 임팩트햄머와 가속도계에서 얻어낸 주파수응답함수(frequency response function)를 신호 분석기(FFT analyzer, Type $3065, \mathrm{~B} \& \mathrm{~K})$ 로 분석하여 고유진동수 $\left(\mathrm{f}_{0}\right)$ 를 측정하였다. 각 시험편은 5 회 가볍게 두드려 평균된 고유진동수 $\left(\mathrm{f}_{0}\right)$ 를 이용하여 회전관성과 전단영향을 고려한 공진주파수(resonance frequency, f)를 계산하고, 이 공진주파수를 이용하여 동적탄성계수 $(\mathrm{dMOE})$ 를 구하였다. 공진주파수와 동적 탄성계수는 각각 식 (1)과 식 (2)를 이용하여 계산하였다 (Kataoka and Ono, 1975).

$$
f=f_{0}\left(1+\frac{a h^{2}}{l^{2}}\right)
$$

여기서, $\mathrm{f}_{0}$ 은 고유진동수(주파수 분석기에서 얻어진 값), $\mathrm{a}$ 는 진동형태에 의한 상수 $8.2, \mathrm{~h}$ 는 시험편 두께, 1 은 시험편의 길이이다. 식(1)에서 보정한 공진주파수 $\mathrm{f}$ 를 식 (2)를 이용하여 동적탄성계수를 구하였다.

$$
{ }_{d} M O E=\frac{48 \pi^{2} p l^{4} f^{2}}{m^{4} h^{2}}
$$

여기서, $\rho$ 는 밀도, 1 은 시험편길이, $\mathrm{f}$ 는 공진주파수, $\mathrm{m}$ 은 기본 진동에 의한 상수로서 $4.73, \mathrm{~h}$ 는 시험편 두께이다.

\subsection{2. 휨시험}

제조된 보드의 휨강도는 한국산업규격 KS F 3104-2016에 따라 실시하였다. 만능강도시험기(Shimadsu, AGS-10 kN, Autograph)를 이용하여 하중속도 $10 \mathrm{~mm} / \mathrm{min}$ 조건으로 측정했고 식 (3)과 식 (4)를 이용하여 정적 탄성계수(sMOE)와 휨 강도 (MOR)를 구하였다.

$$
{ }_{s} M O E=\frac{P l^{3}}{4 b h^{3} y}
$$

여기서, $\mathrm{P}$ 는 하중, 1 은 스팬길이, $\mathrm{b}$ 는 시험편의 폭, $\mathrm{h}$ 는 시험편의 두께, $\mathrm{y}$ 는 변위이다.

$$
M O R=\frac{3 P l}{2 b h^{2}}
$$

여기서, $\mathrm{P}$ 는 최대하중, 1 은 스팬길이, $\mathrm{b}$ 는 시험편의 폭, $\mathrm{h}$ 는 시험편의 두께이다. 


\section{3. 결과 및 고찰}

\section{1. 수지 첨가량이 역학적 성능에 미치는 영향}

밀도를 $0.6 \mathrm{~g} / \mathrm{cm}^{3}$, 톱밥 첨가율을 $10 \%$ 로 고정한 후 수지 첨가율에 따라 제조된 보드의 공진주파수, 휨강도, 정적 휨 탄성계수, 동적 탄성계수의 값을 Table 2에 나타냈다. 왕겨숯-톱밥 혼합보드의 수지 첨가율이 $10 \%$ 에서 $25 \%$ 까지 점차적으로 증가할 때 공진 주파수는 $227.53 \sim 333.63 \mathrm{~Hz}$, 휨강도는 $9.22 ~ 28.91 \mathrm{MPa}$, 동적탄성계수는 $320.62 \sim 963.48 \mathrm{MPa}$ 그리고 정적 휨 탄성계수는 92.06 322.92MPa의 범위를 나타냈다. 전체적으로 공진주파수, 휨강도, 동적탄성계수, 정적 휨 탄성계수는 수지 첨가율이 증가함에 따라 모두 증가하는 경향을 나타냈다. 이러한 결과는 보드 제조 시 수지 첨가율이 증가 할수록 시료간의 결합력이 증대되었다고 보고한 Kawai et al. (1986), Lee and Yoon (1994) 및 Oh et al. (2012)의 연구에서 수지 첨가율이 증가할수록 휨강도가 증가한다는 내용과 비슷한 경향을 나타냈다. 또한 수지 첨가율 $15 \%$ 로 제조한 보드의 휨강도는 $\mathrm{KS} \mathrm{F}$ 3104 파티클보드의 품질기준 15.0 형에 만족시켰고 수지 첨가율 $20 \%$ 와 $25 \%$ 로 제조한 보드는 18.0 형에 만족시켰다. 이는 역학적 성능측면에서 수지첨가율 $25 \%$ 로 제조한 왕겨숯-톱밥 혼합보드가 최적의 조건으로 보인다.

Fig. 1은 수지 첨가율이 왕겨숯-톱밥 혼합보드의 강도적 성능에 미치는 영향을 파악하고자 보드의 수지첨가율과 휨강도, 동적탄성계수 및 정적 휨 탄성계수와의 상관관계를 분석한 결과이다. 수지첨가율과 휨강도, 동적 및 정적 휨 탄성계수사이는 선형 상관관계를 이루며 결정계수의 값 $\left(\mathrm{R}^{2}\right)$ 은 $0.7474,0.7363,0.7738$ 로써 유의수준 $1 \%$ 에서 유의성이 인정되어 수지 첨가율이 왕겨숫-톱밥 혼합보드의 기계적 성질에 큰 영향을 주는 주요인자인 것으로 나타났다. 이 결과로부터 왕겨숫-톱밥 혼합보드의 수지첨가량으로부터 동적 및 정적탄성계수, 휨강도의 예측이 가능할 것으로 판단된다.

\section{2. 톱밥첨가량이 역학적 성능에 미치는 영향}

밀도를 $0.6 \mathrm{~g} / \mathrm{cm}^{3}$, 수지 첨가율을 $10 \%$ 로 고정한 후 톱밥 첨가율에 따라 제조된 보드의 공진주파수, 휨강도, 정적 휨 탄성계수, 동적 탄성계수의 값을 Table 3 에 나타냈다. 왕겨숯-톱밥 혼합보드의 톱밥 첨가율이 $10 \%$ 에서 $30 \%$ 로 증가할 때 공진 주파수는 $222.73 \sim 244.82 \mathrm{~Hz}$, 휨강도는 $8.41 \sim 12.46 \mathrm{MPa}$, 동적탄성계수는 $320.62 \sim 367.81 \mathrm{MPa}$ 그리고 정적 휨 탄성계수는 $86.50 \sim$ $106.54 \mathrm{MPa}$ 의 범위를 나타냈다. 전체적으로 톱밥첨가량이 증가할수록 공진주파수, 휨강도, 동적 및 정적 휨 탄성계수는 완만히 증가하는 경향을 나타냈다. 이것은 원료의 사이즈가 크고 탄성계수가 왕겨솣보다 높은 톱밥의 기여가 증가하고 톱밥보다 탄성계 수가 낮은 숯의 기여가 감소하기 때문이라고 사료된다. 이는 파티클보드에 강도성능이 낮은 이종재료의 배합비율이 증가할수록 강도성능이 감소한다는 다수의 연구결과와 일치하였다(Park et al., 2011, 2012, 2013; Jin et al., 2015). 하지만 톱밥 첨가율별로 제조한 보드의 휨강도는 KS F 3104 파티클보드의 품질기준에는 8형에 만족시켰지만 내구성이 있는 곳에 사용이 힘들 것으로 사료된다.

톱밥 첨가율이 왕겨숯-톱밥 혼합보드의 강도적 성능에 미치는 영향을 파악하고자 보드의 톱밥 첨가율과 휨강도, 동적탄성계수 및 정적 휨 탄성계수와의 상관관계를 분석한 결과인 Fig. 2 를 보면 톱밥 첨가율과 휨강도, 동적 및 정적 휨 탄성계수사이는 결정계수의 값 $\left(\mathrm{R}^{2}\right)$ 은 $0.4012,0.0809,0.1971$ 로써 다소 낮은 상관관계를 나타냈는데 이는 톱밥 첨가율이 휨강도성능에 미치는 영향이 미비하다고 볼수 있다. 또한 톱밥첨가율과 동적 및 휨 탄성계수사이의 관계에서 $1 \%$ 유의성 없는 낮은 결과를 나타내었다. 이는 혼합보드의 낮은 톱밥 첨가율로 인해 첨가율에 대한 효과가 미비했기 때문이라고 생각된다. 이 후 연구에서는 역학적 성능의 향상을 위한 최적의 제조조건을 파악하기 위하여 다양한 톱밥의 첨가율로 추가적인 실험이 필요하다고 보인다.

\section{3. 동적탄성계수와 정적 휨강도성능과의 관계}

Table 4는 수지 첨가율별, 톱밥 첨가율별로 제조된 보드의 동적탄성계수와 정적탄성계수 및 휨강도와의 상관관계를 나타냈다. 수지 첨가율별로 제조된 왕겨숯-톱밥 혼합보드 전체의 동적탄성계수와 정적탄성계수 및 휨강도와의 관계는 결정계수의 값 $\left(\mathrm{R}^{2}\right)$ 이 각각 $0.9521,0.8948$ 로 신뢰수준 $1 \%$ 의 유의성이 인정되는 아주 높은 상관관계를 나타내었다. 또한 톱밥 첨가율별로 제조된 혼합보드 전체의 동적탄성계수와 정적탄성계수 및 휨강도와의 관계는 결정계수의 값 $\left(\mathrm{R}^{2}\right)$ 이 각각 $0.7797,0.7200$ 으로 이 역시 신뢰수준 $1 \%$ 의 유의성이 인정되는 높은 상관관계를 나타냈다. Fig. 3 은 왕겨숯-톱밥 혼합보드의 수지 첨가율, 톱밥 첨가율에 관계없이 혼합보드 전체를 통합하여 동적탄성계수와 정적탄성계수 및 휨강도와의 상관회귀그래프를 나타냈다. 동적탄성계수와 정적탄성계수 및 휨강도 사이 결정계수의 값 $\left(\mathrm{R}^{2}\right)$ 는 각각 $0.9612,0.9122$ 로 아주 높은 상관관계를 나타내었다. 이 결과는 목재 및 목질재료의 동적탄성계수와 정적 탄성계수 및 휨강도사이에 밀접한 상관을 나타낸다는 많은 연구보고와 일치한다(Park et al., 2011, 2012; Jin et al., 2015). 따라서 양단 자유 휨진동 실험으로 얻은 동적탄성계수로부터 정적탄성계수와 휨강도의 


\section{Mechanical Performances of Boards Made from Carbonized Rice Husk and Sawdust:}

The Effect of Resin and Sawdust Addition Ratio

예측이 가능할 것으로 사료된다.

\section{4. 결 론}

쌀의 도정과정에서 발생되는 농업부산물인 왕겨를 탄화시켜 만든 왕겨숯과 톱밥을 이용하여 수지 첨가율, 톱밥 첨가율별로 보드를 제조하고 수지 첨가율과 톱밥 첨가율이 동적·정적탄성계수 및 휨강도에 미치는 영향과 동적탄성계수와 정적탄성계수 및 휨강도사이의 관계를 조사하여 다음의 결과를 얻었다.

1) 왕겨숫-톱밥 혼합보드의 수지 첨가율이 $10 \sim 25 \%$ 로 증가할수록 휨성능이 증가하여 수지 첨가율이 휨성능에 크게 영향하였다.

2) 톱밥 첨가율이 증가할수록 휨성능도 완만하게 증가하였지만, 톱밥첨가율과 휨강도, 동적 및 정적 휨 탄성계수사이는 결정계수의 값(R2)은 $0.4012,0.0809,0.1971$ 로써 다소 낮은 상관관계를 나타내 톱밥 첨가율이 휨성능에 미치는 영향이 미비하였다.

3) 왕겨숯-톱밥 혼합보드의 동적탄성계수와 정적탄성계수 및 휨강도사이에 높은 상관 관계가 확인되어 동적탄성계수로부터 비 파괴적으로 정적탄성계수와 휨강도의 예측이 가능한 것으로 확인되었다.

추후, 톱밥의 첨가량을 $25 \%$ 이상으로 증가시키고 수지첨가량의 비율을 감소시켜서 제조하는 실험이 필요할 것으로 보인다. 